\title{
Nutrient supply from organic amendments applied to unvegetated soil, lettuce and orchardgrass
}

\author{
A. M. Hammermeister ${ }^{1}$, T. Astatkie ${ }^{2}$, E. A. Jeliazkova ${ }^{3}$, P. R. Warman ${ }^{3}$, and R. C. Martin ${ }^{1}$ \\ ${ }^{1}$ Organic Agriculture Centre of Canada, ${ }^{2}$ Department of Engineering, ${ }^{3}$ Department of Environmental \\ Sciences, Nova Scotia Agricultural College, Box 550, Truro, Nova Scotia, Canada B2N 5E3. \\ Received 17 March 2005, accepted 13 October 2005.
}

\begin{abstract}
Hammermeister, A. M., Astatkie, T., Jeliazkova, E. A., Warman, P. R. and Martin, R. C. 2006. Nutrient supply from organic amendments applied to unvegetated soil, lettuce and orchardgrass. Can. J. Soil Sci. 86: 21-33. Organic sources of nutrients are increasingly being used in horticultural and certified organic production. The nutrient-supplying potentials of poultry manure compost (PM), feather meal (FM), alfalfa meal (AA) and vermicastings (VC) and an unamended control were measured in a growth room experiment. The amendments were applied at rates equivalent to 200,400 and $800 \mathrm{~kg}$ total $\mathrm{N}^{-1}$ to a soil of low fertility. Nitrogen supply rates and concentrations were measured over 6 mo in unvegetated pots using PRS ${ }^{\mathrm{TM}}$ probes and $\mathrm{KCl}$ extraction, respectively. Biomass of lettuce (Lactuca sativa L.) and orchardgrass (Dactylis glomerata L.) and N uptake of orchardgrass were measured. Repeated measures analysis revealed significant amendment $\times$ rate $\times$ time interaction effects for $\mathrm{N}$ supply rate and concentration. Of total $\mathrm{N}$ applied, available $\mathrm{N}$ was 50 to $70 \%$ in the FM and PM treatments, 10 to $40 \%$ in the AA treatments, and $10 \%$ in the VC treatments. High rates of FM and PM were toxic to lettuce but produced good orchardgrass yields. VC was safe for lettuce but low $\mathrm{N}$ availability limited long-term orchardgrass growth. Higher application rates did not result in corresponding increases in nutrient supply. Consideration should be given to balancing the ratio of available nutrients in amendments with plant requirements.
\end{abstract}

Key words: Apparent nitrogen recovery, plant $\mathrm{N}$ uptake, feather meal, alfalfa meal, vermicastings, poultry manure compost

\begin{abstract}
Hammermeister, A. M., Astatkie, T., Jeliazkova, E. A., Warman, P. R. et Martin, R. C. 2006. Apport en éléments nutritifs des amendements biologiques appliqués sur du sol nu, de la laitue et du dactyle pelotonné. Can. J. Soil Sci. 86: 21-33. Les horticulteurs et les producteurs agréés pratiquant l'agriculture biologique recourent de plus en plus à des amendements d'origine biologique. Les auteurs ont mesuré l'apport potentiel d'éléments nutritifs du compost de volaille (CV), de la farine de plumes (FP), de la farine de luzerne (FL), du fumier de vers de terre $(\mathrm{FV})$ et d'un sol non amendé servant de témoin lors d'une expérience en phytotron. Les amendements ont été appliqués à un taux correspondant à 200, 400 et $800 \mathrm{~kg}$ de $\mathrm{N}$ total par hectare sur un sol peu fertile. L'apport et la concentration d'azote ont respectivement été établis pendant 6 mois dans des pots dépourvus de végétation au moyen d'une sonde PRS ${ }^{\mathrm{MD}}$ et par extraction au $\mathrm{KCl}$. Les auteurs ont mesuré la biomasse de la laitue (Lactuca sativa $\mathrm{L}$.) et du dactyle pelotonné (Dactylis glomerata L.) ainsi que l'absorption de N par le dactyle. L'analyse des mesures réitérées révèle une interaction significative amendement ( taux ( temps pour l'apport et la concentration de N. Sur la quantité totale de $\mathrm{N}$ appliquée, 50 à $70 \%$ venait de la FP et du CV, 10 à $40 \%$ de la FL et $10 \%$ du FV. Un taux d'application élevé de FP et de CV s'avère toxique pour la laitue, mais assure un bon rendement de dactyle pelotonné. Le FV est inoffensif pour la laitue, mais la faible quantité de $\mathrm{N}$ réduit la croissance à long terme du dactyle. Un taux d'application supérieur n'entraîne pas de hausse correspondante de l'apport de nutriments. On devrait songer à équilibrer la quantité d'éléments nutritifs disponible avec les besoins de la plante.
\end{abstract}

Mots clés: Rétablissement apparent de l'azote, absorption de N par la plante, farine de plumes, farine de luzerne, fumier de vers de terre, compost de volaille

Organic amendments are increasingly being utilized in alternative and low input production systems, typically in the form of waste by-products of livestock production (e.g., manure and compost), animal processing (e.g., feather meal, blood meal, crab meal), or plant materials (e.g., alfalfa meal, seaweed). Total nutrient content is easily measured; however, there is a need for improving the understanding of the relative timing and amount of nutrient supplied to plants.

Nutrient release from manures and composts can be quite variable ranging from 10 to $40 \%$ of total $\mathrm{N}\left(\mathrm{N}_{\text {tot }}\right)$ (Castellanos and Pratt 1981; Hadas and Portnoy 1994; N'Dayegamiye et al. 1997; Qian and Schoenau 2002a). Good indicators of potential $\mathrm{N}$ mineralization include soluble organic carbon and insoluble organic carbon (Hadas and Portnoy 1994), C:N ratio of manure (Qian and Schoenau 2002a), and Walkley-Black N (Douglas and Magdoff 1991).
N'Dayegamiye et al. (1997) found that most of the manures and composts studied had high $\mathrm{N}$ mineralization rates until labile forms of $\mathrm{N}$ from microbial products were exhausted, followed by a period of slow mineralization of more stable $\mathrm{N}$ forms. Nutrient release may be synchronous with crop needs resulting in more efficient $\mathrm{N}$ utilization (Ma et al. 1999). Warman and Cooper (2000a, b) found that poultry manure compost could provide equivalent nutrient supplies as NPK fertilizers; however, the $\mathrm{P}$ and $\mathrm{K}$ were utilized relatively inefficiently.

Abbreviations: AA, alfalfa meal; AIC, Akaike's Information Criterion; ANR, apparent $\mathrm{N}$ recovery; BIC, Schwarz's Bayesian Criterion; CF, chemical fertilizer; EC, electrical conductivity; FM, feather meal; ICP-AES, inductively coupled plasma emission spectrometry; $\mathbf{N}_{\text {tot }}$, total $\mathrm{N}$; $\mathbf{P M}$, poultry manure compost; VC, vermicastings 
Vermicomposting (i.e., composting with worms) is attracting considerable interest because it is expected to decompose organic materials more quickly and completely with higher availability and lower loss of nutrients than in conventional composting. The nutrient value of vermicompost is receiving increasing attention (Atiyeh et al. 2000; Atiyeh et al. 2001), however, its nutrient supply rate compared with other amendments needs further investigation. Vermicastings are known to have a high initial $\mathrm{NO}_{3}{ }^{-}$content (Parle 1963), which is regarded as an indication of maturity (Jimenez and Garcia 1989). AngLopez and Warman (unpublished) found that three types of vermicomposts produced plants with increased biomass and leaf area but one test plant showed $\mathrm{P}$ deficiency symptoms at the end of the study. However, no significant yield benefit was observed when testing the same composts in a subsequent greenhouse experiment. Thus, the use of vermicomposts for greenhouse crop production requires further evaluation.

With an $\mathrm{N}$ content ranging from 13 to $15 \%$, feather meal has good potential for use as a soil amendment (Hadas and Portnoy 1994; Gagnon and Berrouard 1994). However, N release from feather meal is relatively slow since the $\mathrm{N}$ is in a non-soluble keratin protein form (Choi and Nelson 1996a). Hydrolysis of feather meal has been used to increase the availability of nutrients and improve its value as a livestock feed.

Alfalfa is commonly used as a green manure crop or break crop in alternative farming systems. Ta and Faris (1990) found that effective nitrogen availability from application of alfalfa residues amounted to $18 \%$ of total $\mathrm{N}\left(\mathrm{N}_{\text {tot }}\right)$ applied, with over $60 \%$ of that $\mathrm{N}$ becoming available in the first year. Application of low rates of fertilizer with alfalfa, however, increased the rate of $\mathrm{N}$ availability from the alfalfa. In a qualitative greenhouse tomato evaluation using three rates of alfalfa meal, Moreau (2004) found that the low rate of alfalfa produced plants of inferior quality relative to the control, while the higher rates produced healthier plants. In a concurrent field experiment using two potato cultivars and two rates of alfalfa meal, no difference in yield between the rates of alfalfa meal application was observed (Moreau 2004). Hammermeister (unpublished data) has observed that alfalfa pellets applied to field plots can delay cereal crop development and reduce yields.

A growing body of literature is supporting the use of ion exchange resins to measure ion fluxes in the soil as an indication of soil fertility (Qian and Schoenau 2002b). Compared with conventional methods for soil testing, ion exchange membranes provide the following advantages: a better index of relative nutrient bioavailability, consistency over a wide range of soil types, in situ measurement of nutrient supply over a period of weeks, and simultaneous extraction of all the major nutrient elements, easily and more cost effectively than using conventional techniques (Qian and Schoenau 2002b). Ion exchange membranes have been shown to be an effective tool for measuring available nitrogen in the soil (Qian and Schoenau 1995; Subler et al. 1995; Ziadi et al. 1999). Qian and Schoenau (2002a) found a significant negative correlation between the $\mathrm{C}: \mathrm{N}$ ratio of cattle manure and $\mathrm{N}$ mineralization measured by anion exchange membranes in the form of PRSTM probes. They also found a significant relationship between $\mathrm{N}$ supply rate measured by the PRS ${ }^{\mathrm{TM}}$ probes and $\mathrm{N}_{\text {tot }}$ uptake by canola. Ion exchange resins may be well suited to measuring the slow nutrient release from organic amendments since they can be buried in the soil for extended periods of time.

The objectives of this research were to determine: (a) the relative amount of nutrients supplied by various organic amendments, (b) the effect of amendment and rate on nutrient supply changes over time, and (c) the influence of amendments on crop yield, quality and total nutrient uptake.

\section{MATERIALS AND METHODS}

\section{Experimental Design}

Four organic amendments were compared in a growth room experiment: poultry manure compost (PM), vermicastings (VC) prepared using Eisenia fetida worms (with a feedstock of sheep manure, peat moss and cardboard), feather meal (FM) (hydrolyzed and baked, used for livestock feed), and alfalfa meal (AA) (Table 1). The amendments were applied based on total $\mathrm{N}\left(\mathrm{N}_{\text {tot }}\right)$ analysis at rates of 200,400 , or 800 $\mathrm{mg} \mathrm{N}_{\text {tot }}$ pot $^{-1}$ of $2.25 \mathrm{~kg}$ of soil, roughly equivalent to 200 , 400 or $800 \mathrm{~kg} \mathrm{ha}^{-1}$ respectively. For baseline comparisons, a control treatment with no amendment was included as well as an ammonium-nitrate chemical fertilizer $(\mathrm{CF})$ treatment at rates of 50,100, and $200 \mathrm{mg}$ mineral $\mathrm{N}\left(\mathrm{N}_{\min }\right)$ pot $^{-1}$. The 50,100 and 200 rates of CF were intended to compare with the 200, 400 and 800 rates of the organic amendments, based on a general assumption that $25 \%$ of $\mathrm{N}_{\text {tot }}$ would be available, and were analyzed statistically as such. The $\mathrm{CF}$ treatment also received $\mathrm{P}$ in the form of superphosphate $(0$ 20-0) at rates of 63, 125 and $250 \mathrm{mg} \mathrm{P}^{\mathrm{P}} \mathrm{pot}^{-1}$ and $\mathrm{K}(0-0-50)$ at rates of 50, 100 and $200 \mathrm{mg} \mathrm{K}$ pot $^{-1}$ for the CF50, CF100 and CF200 treatments, respectively. To maximize treatment effect, an impoverished loamy sand soil with low N $(0.02 \%$ $\left.\mathrm{N}_{\text {tot }}\right)$ and low organic matter content $(0.09 \%$ total $\mathrm{C})$ was selected. This soil was an Orthic Humo-Ferric Podzol (Truro Association) prior to complete disturbance of the soil profile by residential development. Mehlich 3 extractable soil nutrient content of the unamended soil was as follows (mg kg${ }^{-1}$ ): P, 1.1; K, 68.8; Ca, 60.2; Mg, 257; Na, 50.5; and $\mathrm{S}, 11$. Lime was applied at a rate of $4 \mathrm{t} \mathrm{ha}^{-1}$ to bring soil from a $\mathrm{pH}$ of 5.3 to 6.5 ; however, the $\mathrm{pH}$ was actually raised to 7.5. Three sets of pots were used: one with no crop, and the other two were planted with lettuce (Lactuca sativa L. 'Grand Rapids') or orchardgrass (Dactylis glomerata L. 'Nordic'). Soil moisture in all pots was maintained close to $17 \%$ by weight ( $75 \%$ of field capacity) by hand watering.

Lettuce and orchardgrass were started from seed and grown in the same but unamended soil used for the experiment for $18 \mathrm{~d}$ (lettuce) and $21 \mathrm{~d}$ (orchardgrass); seedlings were transplanted into pots $5 \mathrm{~d}$ after mixing the soil with the amendments. Five lettuce seedlings were transplanted to each pot and subsequently thinned to two plants after seedling establishment; 10 orchardgrass seedlings were transplanted, and thinned to five seedlings once established. Lettuce growth and development were monitored during the experiment and culminated in above- and below-ground 


\begin{tabular}{|c|c|c|c|c|c|c|c|c|c|c|c|c|}
\hline \multirow[b]{2}{*}{ Amend $^{\mathbf{z}}$} & \multirow{2}{*}{$\begin{array}{c}\mathrm{DM}^{\mathrm{y}} \\
(\%) \\
\end{array}$} & $\mathrm{C}$ & $\mathrm{N}$ & \multicolumn{2}{|c|}{$\mathrm{NH}_{4}{ }^{+}-\mathrm{N}$} & \multirow{2}{*}{$\frac{\mathrm{NO}_{3}{ }^{-}-\mathrm{N}}{\left(\mathrm{mg} \mathrm{kg}^{-1}\right)}$} & $\mathrm{Ca}$ & $\mathrm{P}$ & K & & \multirow[t]{2}{*}{$\mathrm{pH}$} & \multirow{2}{*}{$\frac{\mathrm{EC}}{\left(\mathrm{dS} \mathrm{m}^{-1}\right)}$} \\
\hline & & $\longrightarrow$ & $\left.y^{-1}\right)$ & $\left(\mathrm{mg} \mathrm{g}^{-1}\right)$ & $(\%$ of total $\mathrm{N})$ & & \multicolumn{3}{|c|}{$\left(\mathrm{mg} \mathrm{g}^{-1}\right)$} & & & \\
\hline PM & 92.4 & 267 & 57.8 & 14.10 & 24 & 0.065 & 137.3 & 18.5 & 19.3 & 4.7 & 8.1 & 5.7 \\
\hline FM & 87.8 & 509 & 143.7 & 4.10 & 14 & 0.002 & 3.6 & 2.3 & 1.2 & 14.1 & 5.7 & 1.8 \\
\hline AA & 94.7 & 445 & 30.2 & 14.01 & 10 & 0.063 & 13.3 & 1.8 & 12.2 & 2.0 & 6.1 & 2.8 \\
\hline $\mathrm{VC}$ & 32.4 & 287 & 13.7 & 1.60 & 12 & 1.543 & 45.2 & 2.4 & 7.1 & 6.5 & 6.5 & 1.4 \\
\hline
\end{tabular}

${ }^{\mathbf{z}}$ Amend, amendment treatment; PM, poultry manure compost; FM, feather meal; AA, alfalfa meal; VC, vermicastings.

$\mathbf{y}_{\mathrm{DM}}$, dry matter content of the amendment.

biomass measurements at $58 \mathrm{~d}$ after soil mixing. Orchardgrass biomass was determined by clipping when most of the plants reached a height of $30 \mathrm{~cm}$ at $56 \mathrm{~d}$ and again at $92 \mathrm{~d}$ after soil mixing; plants were clipped to a 10$\mathrm{cm}$ height to allow regrowth. The final harvest of orchardgrass at $136 \mathrm{~d}$ after soil mixing included above- and below-ground biomass. At harvest, plant height was measured and number of plants per pot and overall plant condition were recorded. All plant samples were dried at $55^{\circ} \mathrm{C}$ and ground to $\leq 1 \mathrm{~mm}$. Growth room conditions were as follows: temperature was maintained at $22 \pm 2{ }^{\circ} \mathrm{C}$ (day), $16 \pm$ $2{ }^{\circ} \mathrm{C}$ (night), day length was 14 hours, light intensity at pot surface was $244 \pm 20 \mu \mathrm{E} \mathrm{s}^{-1} \mathrm{~m}^{-2}$.

Four days after amendment application, soil samples were collected from the non-vegetative pots and stored at $4^{\circ} \mathrm{C}$ (for $3 \mathrm{mo}$ ) until determination of electrical conductivity (EC), $\mathrm{pH}$, and $\mathrm{KCl}$ extractable N. Samples from the same pots were collected at 6 mo after soil mixing, and stored at $4{ }^{\circ} \mathrm{C}$ until analyzed for $\mathrm{KCl}$ extractable $\mathrm{NO}_{3}{ }^{-}-\mathrm{N}, \mathrm{NH}_{4}{ }^{+}-\mathrm{N} ; 10$ $\mathrm{g}$ of fresh soil and $50 \mathrm{~mL}$ of $2.0 \mathrm{M} \mathrm{KCl}$ were shaken for 30 min, filtered using a Whatman No. 2 filter paper, and analyzed using an AutoAnalyzer II (Technicon, Tarrytown, NY). Soil EC and pH were measured in a slurry of fresh soil and deionized water (1:1 ratio, vol/vol). The EC and $\mathrm{pH}$ of amendments $[1: 5(\mathrm{vol} / \mathrm{vol})$ and $1: 2(\mathrm{vol} / \mathrm{vol})$ ratios of amendment to deionized water, shaken for $0.5 \mathrm{~h}$ ] were measured with a $\mathrm{pH} /$ conductivity meter (Accumet $\mathrm{pH}$ Meter 50, Fisher Scientific, Hampton, NH).

Plant Root Simulator $(\mathrm{PRS})^{\mathrm{TM}}$ probes (Western Ag Innovations Inc., Saskatoon, SK), consisting of cation- and anion-exchange resin membranes enclosed in a plastic holding device, were inserted into soil to measure nutrient flux in situ with minimal disturbance (Qian and Schoenau 2002a). The PRS ${ }^{\mathrm{TM}}$ probes were inserted into non-vegetated pots immediately after soil and amendments were mixed and moisture content was brought to $75 \%$ of field capacity. The PRS ${ }^{\mathrm{TM}}$ probes were removed and replaced with fresh resin membranes in the exact same soil slot location after 4 $\mathrm{d}$ and then again at 2 -wk intervals for six measurement periods (timings) thereafter (i.e., a total of $88 \mathrm{~d}$ ). After $88 \mathrm{~d}$, the pots continued to be maintained in the growth room under the previously described conditions. Six months after the initial mixing, a pair of PRS ${ }^{\mathrm{TM}}$ probes was inserted into each pot for $4 \mathrm{~d}$ to prepare a new slot for measurements followed by a subsequent 2 -wk burial in the same slots. Thus, extracted nutrients were obtained from a total of eight incubation periods with the PRS ${ }^{\mathrm{TM}}$ probes. After removal, the PRS ${ }^{\mathrm{TM}}$ probes were cleaned with deionized water, eluted for $1 \mathrm{~h}$ using $0.5 \mathrm{~N} \mathrm{HCl}$, and the eluate was analyzed for levels of $\mathrm{NH}_{4}{ }^{+}-\mathrm{N}$ and $\mathrm{NO}_{3}{ }^{-}-\mathrm{N}$ using automated colorimetry and for other nutrients by inductively coupled plasma emission spectrometry (ICP-AES) using a Thermo Jarrell Ash PlasmaComp 975 (Franklin, MA) spectrometer.

Amendments and combined root and shoot samples were finely ground $(0.150 \mathrm{~mm})$ for total $\mathrm{C}$ and total $\mathrm{N}$ determination using an automated LECO ${ }^{\circledR}$ CNS Analyzer (CNS-2000, LECO Corp., St. Joseph, MI). The $\mathrm{NO}_{3}-\mathrm{N}$ content of amendments was determined by mixing approximately $10 \mathrm{~g}$ of amendment with $30 \mathrm{~mL}$ of $0.04 \mathrm{M}\left(\mathrm{NH}_{4}\right)_{2} \mathrm{SO}_{4}$, shaken for $15 \mathrm{~min}$, and filtered through a Whatman No. 5 filter paper. The $\mathrm{pH}$ of the extract was adjusted to 4.0 with $0.2 \mathrm{~N} \mathrm{H}_{2} \mathrm{SO}_{4}$ and then measured using an ion selective electrode. Ammonium $\mathrm{N}$ was determined by steam distillation using a Buchi B-324 Distillation Unit; $\mathrm{NH}_{3}$ was distilled, after addition of $\mathrm{NaOH}$, into boric acid solution and titrated with $\mathrm{HCl}$. Other nutrients in the amendments and plant tissue (where sufficient sample remained) were quantified by ICP-AES as above after nitric acid digestion (Zheljazkov and Warman 2002).

\section{Statistical Analysis}

The experimental units were pots placed at four location blocks in a growth chamber and treatment combinations were completely randomized in each block. Repeated measures analysis was completed for four PRS $\left(\mathrm{NO}_{3}{ }^{-} \mathrm{N}, \mathrm{NH}_{4}{ }^{+}-\right.$ $\mathrm{N}, \mathrm{P}, \mathrm{K}^{+}, \mathrm{S}$ ) response variables with eight timing levels. Repeated measures analysis was also completed with two timing levels (1 and 2) for $3 \mathrm{KCl}\left(\mathrm{NO}_{3}{ }^{-} \mathrm{N}, \mathrm{NH}_{4}{ }^{+}-\mathrm{N}, \mathrm{N}_{\min }\right)$ responses and for $\mathrm{PRS} \mathrm{NH}_{4}{ }^{+}-\mathrm{N}$. The design for these responses was a three factor factorial. The factors were: Amend (AA, CF, FM, PM, VC), Rate (200, 400, 800), and Timing with either eight or two levels. The statistical model contained all the seven effects listed in the source of variation column of Table 5. For the purpose of statistical analysis, the CF rates of 50, 100 and 200 were included in ANOVA models as rates of 200, 400 and 800, respectively. Although the model is formulated as a factorial, the levels of timing cannot be randomized, because the response measurements were collected repeatedly over eight or two sampling dates over several months. Since the values of the response variables follow a certain pattern (i.e., it is not random), the independence assumption on the error terms required for the analysis of variance (ANOVA) of a factorial model (Montgomery 2001) was unlikely to be met. 
Generally, with repeated measurements such as this one, two measurements taken at adjacent times are typically more highly correlated than two measurements taken several time points apart (Littell et al. 1998). Therefore, the appropriate assumption on the error terms for these responses was normal distribution with a constant variance, and a covariance structure of $\Sigma$. The appropriate covariance structure for each response variable was determined using Akaike's Information Criterion (AIC) and Schwarz's Bayesian Criterion (BIC) (Littell et al. 1996). We used the Mixed Procedure in SAS software (SAS Institute, Inc. 1999), specifically written for analyzing mixed effects and repeated measures with several choices of covariance structures, to analyze our data. According to the AIC and the $\mathrm{BIC}$, the best covariance structure for all responses was determined to be Compound Symmetry.

For variables measured using the PRS ${ }^{\mathrm{TM}}$ probes, a cumulative value was determined as the sum of all eight sampling timings. The design for the cumulative PRS ${ }^{\mathrm{TM}}\left(\mathrm{NO}_{3}{ }^{-} \mathrm{N}\right.$, $\left.\mathrm{NH}_{4}{ }^{+}-\mathrm{N}, \mathrm{P}, \mathrm{K}^{+}, \mathrm{S}\right), \mathrm{KCl}\left(\mathrm{NO}_{3}{ }^{-}-\mathrm{N}, \mathrm{NH}_{4}{ }^{+}-\mathrm{N}, \mathrm{N}_{\text {min }}\right)$, lettuce and orchardgrass biomasses (shoot, root, total), plant $\mathrm{N}$ concentration and $\mathrm{N}$ uptake for orchardgrass response variables was an unbalanced two-factor factorial of Amend (AA, CF, FM, PM, VC, and control) and Rate (200, 400, 800). This was unbalanced because there was only one rate of zero for the control. In a preliminary analysis, the normalities of the error terms for some of the response variables were found to be violated on the original scale, but were met with either square root or cubic root transformation.

Means comparison results, starting with the highest order significant interaction, were completed by generating letter groupings of the least squares means. Since these significant interactions gave a relatively large number of treatment combinations, the letter groupings were generated using a $1 \%$ level of significance to avoid the inflation of Type I error (SAS Institute, Inc. 1999). Square root transformation was used for PRSTM cumulative $\mathrm{NH}_{4}{ }^{+}-\mathrm{N}, \mathrm{K}+$, individual timings of $\mathrm{PRS}^{\mathrm{TM}} \mathrm{NH}_{4}{ }^{+}-\mathrm{N}, \mathrm{K}+$ and $\mathrm{S}, \mathrm{KCl}$ extractable $\mathrm{NH}_{4}{ }^{+}-\mathrm{N}$ and $\mathrm{N}_{\text {min }}$, orchardgrass $\mathrm{N}$ uptake and lettuce root biomass. Cubic root transformation was used for orchardgrass shoot and root biomass. No other transformations were needed. To facilitate easy reading of the results presented in the tables, the least squares means were back-transformed to the original scale.

\section{RESULTS}

\section{Plant Biomass}

The targeted plant population was not reached consistently for each treatment (Table 2). Plant density was especially reduced in the PM and FM at the 800 rate and to a lesser extent at the 400 rate. Orchardgrass densities in the control and CF were also low relative to other treatments and some plants died during the experiment. Orchardgrass density losses with time were less pronounced in the other treatments.

The VC treatments supported the highest lettuce biomass production (Table 3 ) and first-cut orchardgrass growth (data not shown), however, the VC did not sustain the productivity of the orchardgrass. Although initially suppressed in the
PM800 and FM800 treatments, the orchardgrass thrived with the high available $\mathrm{N}$, which was apparent from the lush green growth. At the time of final harvest, the $\mathrm{VC}, \mathrm{CF}$, and control treatments were pale, lacking vigour and growing slowly. The PM and higher rate FM treatments, however, were still dark green and growing. This resulted in a significant amendment by rate interaction, with biomass increasing with rate, and for a given rate followed the order $\mathrm{PM}>$ $\mathrm{FM}>\mathrm{AA} \geq \mathrm{VC}>\mathrm{CF}=\operatorname{control}($ Table 3$)$.

\section{Nitrogen}

Amendments

Total $\mathrm{N}$ content ranged from $13 \mathrm{mg} \mathrm{g}^{-1}$ in the $\mathrm{VC}$ amendment to $143.7 \mathrm{mg} \mathrm{g}^{-1}$ in the PM amendment (Table 1). The concentration of $\mathrm{NH}_{4}{ }^{+}-\mathrm{N}$ in the amendments was close to 14 $\mathrm{mg} \mathrm{g}^{-1}$ in the PM and AA, $4 \mathrm{mg} \mathrm{g}^{-1}$ in the FM and $<2$ in the VC amendment (Table 1). Ammonium content was $24 \%$ of total $\mathrm{N}$ in the $\mathrm{PM}$ and ranged from 10 to $14 \%$ in the other amendments. Concentration of $\mathrm{NO}_{3}{ }^{-}$in the amendments was very low, but it was notably higher in the $\mathrm{VC}$ than in the other amendments (Table 1).

\section{Cumulative PRS TM Nitrogen Supply Rate}

Cumulative $\mathrm{NO}_{3}{ }^{-}$supply rates were generally higher in the PM and FM treatments than the VC treatment; the AA treatments were generally not significantly different from the other amendments (Table 4). With few exceptions, cumulative $\mathrm{NO}_{3}{ }^{-}$supply rates of all amendment by rate combinations were higher than in the control. The cumulative $\mathrm{NO}_{3}{ }^{-}$supply rate of all three rates of both the FM and PM amendments were equivalent to that of the CF100 and CF200 treatments; $\mathrm{NO}_{3}{ }^{-}$supply of AA rate treatments were incrementally equivalent to that of the $\mathrm{CF}$ rates. The cumulative $\mathrm{NO}_{3}{ }^{-}$supply of all rates of the VC was significantly lower than both CF100 and CF200, but similar to CF50 (Table 4).

A significant amendment by rate interaction was observed for cumulative $\mathrm{NH}_{4}{ }^{+}$(Table 4). At a given rate, $\mathrm{NH}_{4}{ }^{+}$supply rate was higher in the PM and FM than other amended treatments, and was very low in the VC treatments, even when compared with the control. The $\mathrm{NH}_{4}{ }^{+}$ supply of all rates of the CF treatment was significantly lower than all but the PM200 rate of the PM and FM amendments (Table 4). The $\mathrm{NH}_{4}{ }^{+}$supply of AA400 was similar to the CF200 treatment. The $\mathrm{NH}_{4}{ }^{+}$supply rate of $\mathrm{VC}$ was lower than measured in the $\mathrm{CF}$ treatment at all rates.

\section{Timing of Nitrogen Release}

The amendment by rate by timing interaction was not significant for $\mathrm{NO}_{3}^{-}$; however this three-way interaction was significant for $\mathrm{NH}_{4}^{+}$(Table 5). For all amendments, almost all the $\mathrm{NH}_{4}{ }^{+}$(Table 4) was measured during the first two sampling timings totalling $18 \mathrm{~d}$. A large amount of $\mathrm{NO}_{3}{ }^{-}$was measured in the $\mathrm{VC}$ treatments during the first $4 \mathrm{~d}$ (timing 1 ) after mixing, and then declined to a constant but lower level than in the PM, FM, and AA treatments (Fig. 1). This $\mathrm{NO}_{3}{ }^{-}$was most likely present as mineral $\mathrm{N}$ at the time of amendment application as was shown in Table 1 . The $\mathrm{NO}_{3}{ }^{-}$supply rate was high initially, similar to the VC treatment, and then dropped slightly to a continuous supply rate that was similar to the AA (Fig. 


\begin{tabular}{|c|c|c|c|c|c|}
\hline \multirow[b]{2}{*}{ Amend $^{\mathbf{y}}$} & \multirow[b]{2}{*}{$\operatorname{Rate}^{\mathrm{y}}$} & \multirow[b]{2}{*}{ Lettuce } & \multicolumn{3}{|c|}{ Orchardgrass } \\
\hline & & & $56 \mathrm{~d}$ & $92 \mathrm{~d}$ & $136 c$ \\
\hline PM & 200 & 2.0 & 5.0 & 5.0 & 5.0 \\
\hline PM & 400 & 1.8 & 5.0 & 5.0 & 5.0 \\
\hline PM & 800 & 0.3 & 2.3 & 2.3 & 2.3 \\
\hline FM & 200 & 2.0 & 5.0 & 5.0 & 4.5 \\
\hline FM & 400 & 1.0 & 4.5 & 4.5 & 4.5 \\
\hline FM & 800 & 0.0 & 2.5 & 2.5 & 2.5 \\
\hline AA & 200 & 2.0 & 4.8 & 4.5 & 3.8 \\
\hline AA & 400 & 2.0 & 5.0 & 5.0 & 4.3 \\
\hline AA & 800 & 2.0 & 4.8 & 4.8 & 4.3 \\
\hline $\mathrm{VC}$ & 200 & 2.0 & 5.0 & 4.8 & 4.8 \\
\hline $\mathrm{VC}$ & 400 & 2.0 & 5.0 & 5.0 & 5.0 \\
\hline $\mathrm{VC}$ & 800 & 2.0 & 5.0 & 5.0 & 5.0 \\
\hline $\mathrm{CF}$ & 50 & 2.0 & 4.0 & 3.3 & 1.0 \\
\hline $\mathrm{CF}$ & 100 & 2.0 & 3.5 & 3.0 & 1.8 \\
\hline $\mathrm{CF}$ & 200 & 2.0 & 4.3 & 4.3 & 2.5 \\
\hline Control & 0 & 2.0 & 4.8 & 4.0 & 1.8 \\
\hline
\end{tabular}

${ }^{\mathrm{z}}$ Seedlings were initially transplanted into pots at an excess density and later thinned to a density of two plants per pot for lettuce and five plants per pot for orchardgrass.

${ }^{\mathbf{y}}$ Amend, amendment treatment; PM, poultry manure compost; FM, feather meal; AA, alfalfa meal; VC, vermicastings; CF, chemical fertilizer; Rate is mg of total $\mathrm{N}$ applied per pot.

Table 3. Dry weight of lettuce and orchardgrass as affected by amendments and rates

\begin{tabular}{|c|c|c|c|c|c|c|c|}
\hline & \multirow[b]{2}{*}{ Rate $^{z}$} & \multicolumn{3}{|c|}{ Lettuce } & \multicolumn{3}{|c|}{ Orchardgrass } \\
\hline & & Shoot & Root & Total & Shoot $^{\mathbf{y}}$ & Root & Total \\
\hline Source & & \multicolumn{6}{|c|}{ ANOVA P values } \\
\hline Amend & & 0.001 & 0.001 & 0.001 & 0.001 & 0.001 & 0.001 \\
\hline Rate & & 0.051 & 0.524 & 0.058 & 0.001 & 0.001 & 0.001 \\
\hline Amend*Rate & & 0.001 & 0.001 & 0.001 & 0.001 & 0.002 & 0.001 \\
\hline Amend & & \multicolumn{6}{|c|}{ LS means } \\
\hline PM & 200 & $1256 b c d$ & $267 c d$ & $1538 b c d e$ & $4516 c$ & $3239 b c$ & $7820 c$ \\
\hline PM & 400 & $378 e f g h$ & $103 d e$ & $499 f g h$ & $8368 b$ & $4619 b$ & $12995 b$ \\
\hline PM & 800 & $15.2 \mathrm{~h}$ & $2.0 f$ & $18.5 \mathrm{~h}$ & $12816 a$ & $6437 a$ & $19372 a$ \\
\hline FM & 200 & $274 g h$ & $84.6 d e$ & $374 g h$ & $2211 d e$ & $831 e f$ & $3089 e f$ \\
\hline FM & 400 & $61.6 g h$ & $15.0 e f$ & $82.1 g h$ & $4376 c$ & $1812 d$ & $6270 d$ \\
\hline FM & 800 & $0.0 h$ & $0.0 f$ & $0.0 h$ & $7906 b$ & $3996 b c$ & $11980 b$ \\
\hline AA & 200 & 614 efg & $264 c d$ & 898efg & $1343 e f$ & $287 g$ & $2621 \mathrm{fg}$ \\
\hline AA & 400 & $1360 b c$ & $430 b c$ & $1798 b c d$ & $2206 d e$ & $499 f g$ & $2719 f g$ \\
\hline AA & 800 & $998 c d e$ & $360 b c$ & $1363 c d e$ & $8313 b$ & $3080 b c$ & $9526 c$ \\
\hline $\mathrm{VC}$ & 200 & $1361 b c$ & $646 b$ & $2033 b c$ & $1554 d e$ & $1596 \mathrm{de}$ & 3161 ef \\
\hline $\mathrm{VC}$ & 400 & $1720 b$ & $509 b c$ & $2243.0 \mathrm{~b}$ & $2399 d$ & $2571 \mathrm{~cd}$ & $4997 d e$ \\
\hline VC & 800 & $3136 a$ & $1144 a$ & $4300 a$ & $4405 c$ & $4053 b c$ & $8468 c$ \\
\hline $\mathrm{CF}$ & 50 & $332 f g h$ & $120 d e$ & $455 f g h$ & $134 h$ & $62 h$ & $200 h$ \\
\hline $\mathrm{CF}$ & 100 & 596efg & $269 c d$ & 892 efg & $539 g$ & $57 h$ & $890 g h$ \\
\hline $\mathrm{CF}$ & 200 & 884def & $289 c d$ & 1174 def & $739 f g$ & $224 g h$ & $988 g h$ \\
\hline Control & 0 & $311 \mathrm{fgh}$ & $119 \mathrm{de}$ & $431 f g h$ & $431 \mathrm{~g}$ & $457 f g$ & $922 g h$ \\
\hline
\end{tabular}

${ }^{\mathbf{z}}$ Amend, amendment treatment; PM, poultry manure compost; FM, feather meal; AA, alfalfa meal; VC, vermicastings; CF, chemical fertilizer; Rate is mg of total $\mathrm{N}$ applied per pot.

${ }^{\mathbf{y}}$ Cumulative dry weight from all orchardgrass clippings.

$a-h$ Within each response, means followed by the same letter are not significantly different at the $1 \%$ level. 


\begin{tabular}{|c|c|c|c|c|c|c|}
\hline & Rate $^{\mathbf{z}}$ & $\mathrm{NO}_{3}{ }^{-}-\mathrm{N}$ & $\mathrm{NH}_{4}{ }^{+}-\mathrm{N}$ & $\mathrm{P}$ & $\mathrm{K}^{+}$ & $\mathrm{S}$ \\
\hline Source & & \multicolumn{5}{|c|}{ ANOVA $P$ values } \\
\hline Amend & & 0.001 & 0.001 & 0.001 & 0.001 & 0.001 \\
\hline Rate & & 0.001 & 0.001 & 0.476 & 0.001 & 0.501 \\
\hline Amend $>$ & & 0.101 & 0.001 & 0.042 & 0.001 & 0.561 \\
\hline Amend $y$ & & \multicolumn{5}{|c|}{$\begin{array}{c}\text { LS means } \\
10 \mathrm{~cm}^{-2} 88\end{array}$} \\
\hline PM & 200 & $1844 a b c$ & $220 c$ & $5.5 b c d e$ & $325 e f$ & $337 e f$ \\
\hline PM & 400 & $1946 a b c$ & $331 c$ & $6.7 a b c$ & $479 c d e$ & $340 e f$ \\
\hline PM & 800 & $1976 a b c$ & $1339 a$ & $8.0 a b$ & $1280 b$ & $259 e f$ \\
\hline FM & 200 & $1871 a b c$ & $87 d e$ & $4.0 \mathrm{de}$ & $104 h$ & $338 e f$ \\
\hline FM & 400 & $1739 b c d$ & $258 c$ & $4.5 c d e$ & $110 h$ & 389 def \\
\hline FM & 800 & $2348 a$ & $1026 b$ & $5.5 b c d e$ & $154 g h$ & $338 e f$ \\
\hline AA & 200 & $1262 d e$ & $29 f g$ & $4.7 c d e$ & $438 d e$ & $296 e f$ \\
\hline AA & 400 & $1503 c d$ & $82 d e$ & $6.0 a b c d$ & $712 c$ & $235 f$ \\
\hline AA & 800 & $1700 b c d$ & $254 c$ & $6.1 a b c d$ & $1448 b$ & $225 f$ \\
\hline $\mathrm{VC}$ & 200 & $909 e f$ & $7 g h$ & $5.7 a b c d$ & $554 c d$ & $918 a$ \\
\hline $\mathrm{VC}$ & 400 & $837 e f$ & $1 h$ & $3.3 e$ & $1216 b$ & $792 a b$ \\
\hline VC & 800 & $1217 d e$ & $0 h$ & $3.8 d e$ & $2174 a$ & $948 a$ \\
\hline $\mathrm{CF}$ & 50 & $1239 \mathrm{de}$ & $26 f g$ & $5.0 \mathrm{cde}$ & $123 g h$ & $622 b c d$ \\
\hline $\mathrm{CF}$ & 100 & $1828 a b c$ & $35.7 e f$ & $3.8 \mathrm{de}$ & $130 g h$ & $651 b c$ \\
\hline $\mathrm{CF}$ & 200 & $2163 a b$ & $91 d$ & $3.5 e$ & $250 f g$ & $498 c d e$ \\
\hline Control & 0 & $505 f$ & $13 f g$ & $8.4 a$ & $69 h$ & $469 c d e f$ \\
\hline
\end{tabular}

$a-h$ Means within a column followed by the same letter are not significantly different at the $1 \%$ level.

${ }^{\mathbf{z}}$ Rate analyses included the CF treatment where actual $\mathrm{N}_{\text {tot }}$ rates of 50,100 and $200 \mathrm{mg}$ total $\mathrm{N}_{\text {pot }}{ }^{-1}$ were analyzed with the 200 , 400 and 800 mg total $\mathrm{N}$ pot $^{-1}$ rates of the organic amendments, respectively.

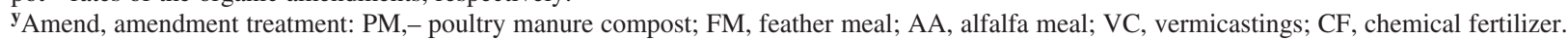

\begin{tabular}{|c|c|c|c|c|c|}
\hline Source $e^{y}$ & $\mathrm{NO}_{3}{ }^{-}-\mathrm{N}$ & $\mathrm{NH}_{4}{ }^{+}-\mathrm{N}$ & $\mathrm{P}$ & $\mathrm{K}^{+}$ & $\mathrm{S}$ \\
\hline Amend & 0.001 & 0.001 & 0.001 & 0.001 & 0.001 \\
\hline Rate & 0.001 & 0.001 & 0.412 & 0.001 & 0.105 \\
\hline Amend $\times$ Rate & 0.058 & 0.001 & 0.003 & 0.001 & 0.503 \\
\hline Tim & 0.001 & 0.330 & 0.001 & 0.001 & 0.001 \\
\hline Amend $\times$ Tim & 0.001 & 0.001 & 0.001 & 0.001 & 0.001 \\
\hline Rate $\times$ Tim & 0.001 & 0.001 & 0.004 & 0.046 & 0.001 \\
\hline Amend $\times$ Rate $\times$ Tim & 0.276 & 0.001 & 0.054 & 0.026 & 0.097 \\
\hline
\end{tabular}

${ }^{\mathrm{z}}$ Only the first two timings were included for $\mathrm{NH}_{4}{ }^{+}-\mathrm{N}$, all eight measurement timings were used for other variables.

${ }^{\mathbf{y}}$ Amend, amendment treatment; Tim, timing of measurement.

1). After an initial high supply rate of $\mathrm{NH}_{4}{ }^{+}$but low supply of $\mathrm{NO}_{3}{ }^{-}$, the PM, FM and to a lesser extent AA treatments were characterized by relatively high and steady $\mathrm{NO}_{3}{ }^{-}$supply rates in timings 3-7 (Fig. 1). There was no significant difference in the combined supply rate of $\mathrm{NO}_{3}{ }^{-}$and $\mathrm{NH}_{4}{ }^{+}$(i.e., $\mathrm{N}_{\text {min }}$ ) between the VC, PM and FM treatments during the first three timings (data not shown). At timing 8 (i.e., after $6 \mathrm{mo}$ ), $\mathrm{NO}_{3}{ }^{-}$ supply rate was lower than at timing 7 for all treatments, but differences between timings were not analyzed statistically.

Amendment application rate had little influence on $\mathrm{NO}_{3}{ }^{-}$ supply rate (Fig. 1). Throughout the measurement timings, the only significant difference in $\mathrm{NO}_{3}{ }^{-}$supply rate between the 200 and 400 rates was at timings 5 and 7 . The 800 rate was only significantly higher than the 200 rate at three timings, and higher than the 400 rate at two timings.

\section{KCl Extractable $N$}

The mineralized $\mathrm{N}$ results determined by $\mathrm{KCl}$ extraction were generally comparable with that of the PRS ${ }^{\mathrm{TM}}$ probes in terms of treatment trends. Soil $\mathrm{N}_{\min }$ content was lower in the final analysis than the initial analysis for several treatments suggesting the loss of $\mathrm{N}$ with time (Table 6). Accumulation of $\mathrm{N}_{\text {min }}$ was higher in the 800 rates of the AA, PM and FM amendments and lowest in the VC treatments and the 200 rates of the $\mathrm{CF}$ and $\mathrm{AA}$ amendments.

Both $\mathrm{NH}_{4}{ }^{+}$and $\mathrm{NO}_{3}{ }^{-}$contributed to $\mathrm{N}_{\text {min }}$ at $4 \mathrm{~d}$ in all amendments except for $\mathrm{VC}$ where $\mathrm{N}$ was in the form of $\mathrm{NO}_{3}{ }^{-}$only (Table 6). At the final sampling timing, essentially all $\mathrm{N}_{\min }$ was in the form of $\mathrm{NO}_{3}^{-}$. The initial $\mathrm{NO}_{3}^{-}$levels were highest in the $\mathrm{VC}$ and $\mathrm{CF}$ amendments, although differences were not statistically significant. There were sig- 

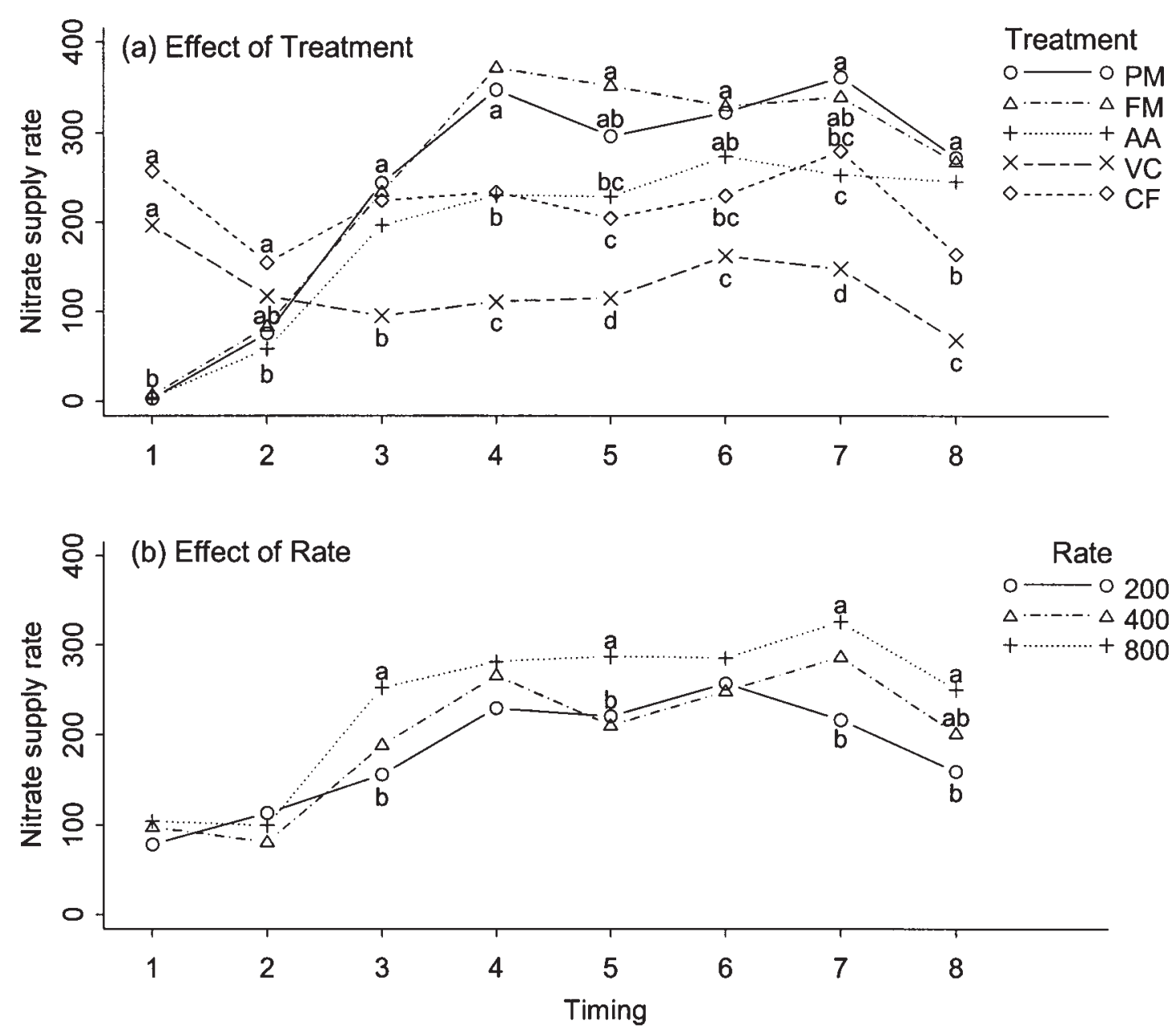

Fig. 1. Mean nitrate supply rates ( $\mu \mathrm{g} 10 \mathrm{~cm}^{-2}$ ) measured using PRSTM probes showing (a) amendment effect (all rates combined), and (b) rate effect (all amendments combined). Timing 1 was a 4-d burial immediately after mixing amendments into the soil, with consecutive 14$\mathrm{d}$ burials for timings 2-7; timing 8 was buried for $14 \mathrm{~d} 6$ mo after soil mixing. Means within a timing followed by the same letter are not significantly different at the $1 \%$ level. Amendments are: PM, poultry manure compost; FM, feather meal; AA, alfalfa meal; VC, vermicastings; $\mathrm{CF}$, chemical fertilizer; Treatment, amendment treatment. Rate analyses included the CF treatment where actual $\mathrm{N}_{\text {tot }}$ rates of 50, 100 and $200 \mathrm{mg} \mathrm{N}_{\text {tot }}$ pot $^{-1}$ were analyzed with the 200,400 and $800 \mathrm{mg} \mathrm{N}_{\text {tot }}$ pot $^{-1}$ rates of the organic amendments, respectively.

nificant differences in the initial $\mathrm{NH}_{4}{ }^{+}$values, again with the FM and PM having the highest values and the VC having virtually no $\mathrm{NH}_{4}^{+}$.

\section{Plant N}

Both amendment and rate had significant influences on $\mathrm{N}$ concentration in plant tissue; however, the interaction was only significant for orchardgrass (Table 7). Low N concentration was observed for the VC treatments in both crops. The PM treatments responded differently between crops with low $\mathrm{N}$ concentration in orchardgrass but high $\mathrm{N}$ concentration in lettuce. Nitrogen concentration for the AA treatments was high in the orchardgrass and medium relative to other amendments in lettuce. The $\mathrm{N}$ concentration in FM treatments was in the intermediate range for both crops. The effect of rate on $\mathrm{N}$ concentration was inconsistent among the amendments, depending on amendment and crop.

A significant interaction between amendment and rate occurred in orchardgrass for total $\mathrm{N}$ uptake and tissue $\mathrm{N}$ concentration (Table 7). For each amendment, $\mathrm{N}$ uptake increased significantly with each increase in rate. Among the amendments, $\mathrm{N}$ uptake by orchardgrass was highest in the PM and FM and lowest in the VC and CF. Orchardgrass N-uptake at the 200 rate of the FM and PM treatments was the same as or greater than N-uptake for the VC800 treatment.

\section{Apparent N Recovery}

To determine the percentage of total $\mathrm{N}$ in the amendment that could be expected to become available, apparent $\mathrm{N}$ recovery (ANR) was calculated as follows: 


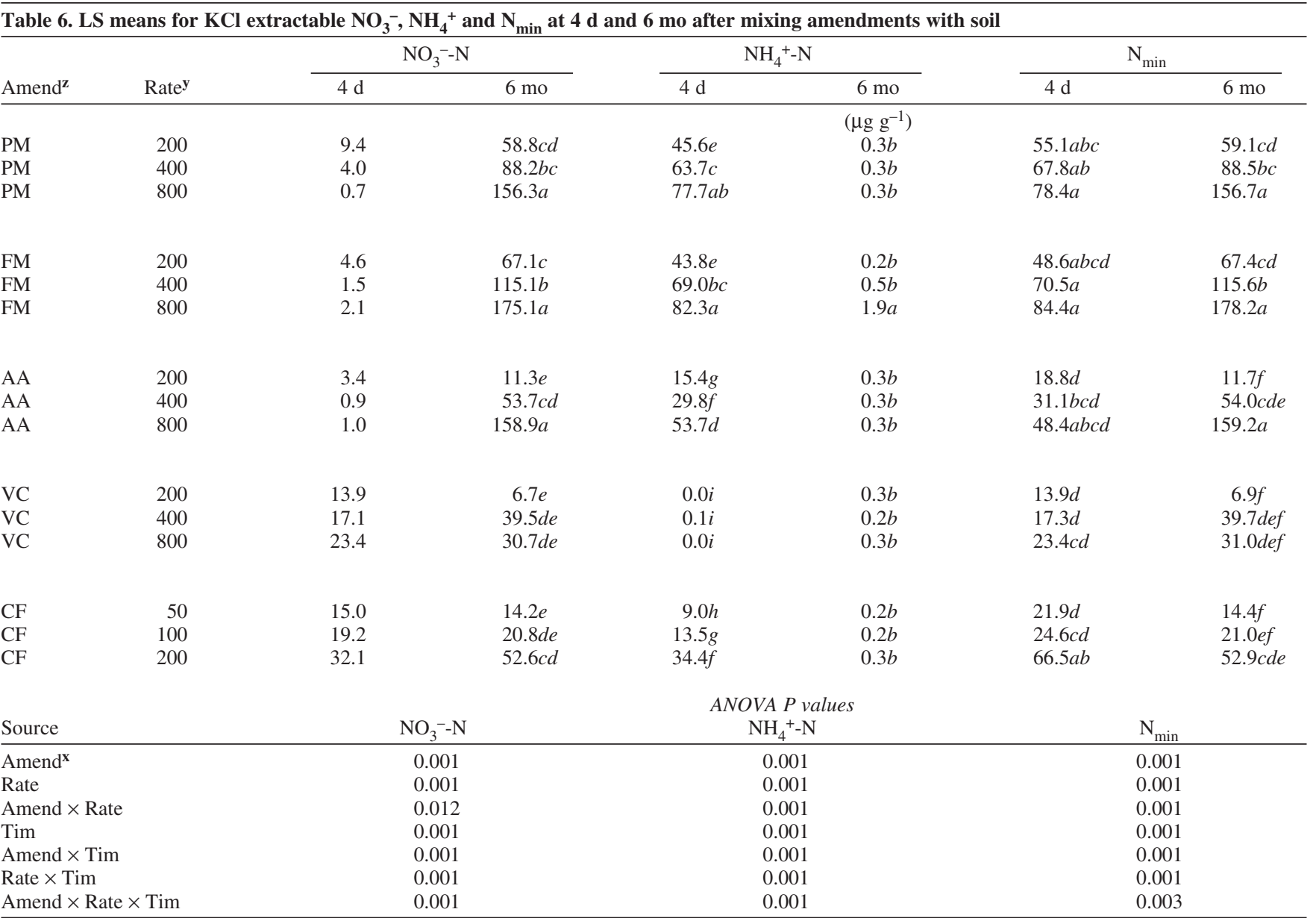

a-g Within each of the two timings, means followed by the same letter are not significantly different at the $1 \%$ level. When no letter is shown, it means there was no significant difference.

zPM, poultry manure compost; FM, feather meal; AA, alfalfa meal; VC, vermicastings; CF, chemical fertilizer; Amend, amendment treatment; Rate is mg of total $\mathrm{N}$ applied per pot.

${ }^{\mathbf{y}}$ The analyses did not include the control, for which $\mathrm{KCl}$ extractable $\mathrm{N}_{\min }$ at $4 \mathrm{~d}$ was $6.72 \mu \mathrm{g} \mathrm{g}^{-1}$ and after 6 mo was $2.04 \mu \mathrm{g} \mathrm{g}^{-1}$.

$$
A N R=\frac{N_{M}-N_{c}}{N_{\text {tot }}} \times 100
$$

where $\mathrm{N}_{\mathrm{M}}$ is mineralized soil $\mathrm{N}\left(\mathrm{N}_{\min }\right)$ or orchardgrass tissue $\mathrm{N}$ from amended pots, $\mathrm{N}_{\mathrm{C}}$ is $\mathrm{N}$ measured in the soil or plant tissue of the control pots and $\mathrm{N}_{\text {tot }}$ is total $\mathrm{N}$ applied with the amendment. The $\mathrm{N}_{\min }$ content in unvegetated pots $4 \mathrm{~d}$ and 6 mo after mixing was used for this calculation. After $4 \mathrm{~d}$, the $\mathrm{N}_{\min }$ content of the soil accounted for as little as 5\% of the $\mathrm{N}_{\text {tot }}$ applied in a VC treatment and as high as $73 \%$ in a CF treatment (Table 8). Regardless of the method of calculation, the ANR was greatest in the PM and FM treatments and smallest in the VC treatment. The relationship between ANR and rate varied depending on amendment. ANR decreased with increasing rate in the PM and FM treatments, no differences were found among VC rates, and ANR increased with increasing rate for the AA treatment. The ANR $\left(6 \mathrm{mo} \mathrm{N}_{\min }\right)$ from the FM200 and PM200 treatments was approximately equal to that of the CF200 treatment (highest rate) which provided 65 $\mu \mathrm{g} \mathrm{N} \mathrm{g}^{-1}$ soil, or approximately $130 \mathrm{~kg} \mathrm{~N} \mathrm{ha}^{-1}$.

The ANR as determined by total uptake in orchardgrass was generally smaller than ANR measured by soil $\mathrm{N}_{\text {min }}$, with the exception of the $\mathrm{VC}$ treatments where results were similar to the $\mathrm{N}_{\min }$ values (Table 8). Trends among rates were unclear, with the exception that ANR seemed to increase with AA rate. Averaged across rates, the ANR for orchardgrass was approximately $30 \%$ for PM, $25 \%$ for FM, $15 \%$ for $\mathrm{AA}, 10 \%$ for $\mathrm{VC}$ and very low in the $\mathrm{CF}$ treatment.

\section{Phosphorus, Potassium, Sulphur}

The amendment by rate interaction was significant for cumulative $\mathrm{P}$ and $\mathrm{K}$ but not for $\mathrm{S}$ in unvegetated pots (Table 4). Cumulative $\mathrm{P}$ in the control soil was equal to or higher than that measured in all other treatments. For each amendment, there were few significant differences in cumulative $\mathrm{P}$ among application rates. Cumulative $P$ was lower in the 400 and 800 rates of the VC and CF treatments than at the 200 rates. Differences 


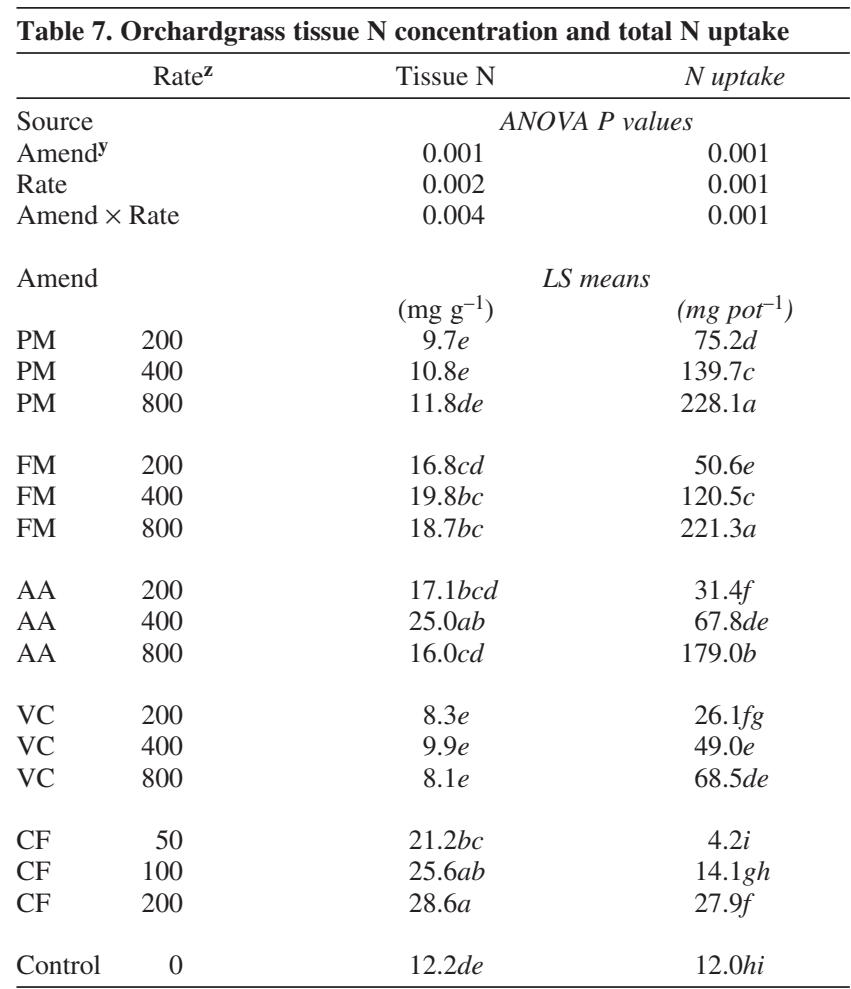

${ }^{\mathrm{z}} \mathrm{PM}$, poultry manure compost; FM, feather meal; AA, alfalfa meal; VC, vermicastings; $\mathrm{CF}$, chemical fertilizer; Amend, amendment treatment; Rate is $\mathrm{mg}$ of total $\mathrm{N}$ applied per pot.

$a-h$ Within each response, means followed by the same letter are not significantly different at the $1 \%$ level.

Table 8. Apparent $\mathrm{N}$ recovery estimated by $\mathrm{N}$ uptake by orchardgrass and $\mathrm{KCl}$ extractable $\mathrm{N}_{\min }$ at two timings after soil mixing with amendments

\begin{tabular}{|c|c|c|c|c|}
\hline \multirow[b]{2}{*}{ Amend $^{\mathbf{Z}}$} & \multirow[b]{2}{*}{ Rate $^{\mathbf{Z}}$} & \multirow[b]{2}{*}{ Orchardgrass } & \multicolumn{2}{|c|}{$\mathrm{N}_{\text {min }}$} \\
\hline & & & $4 \mathrm{~d}$ & $6 \mathrm{mo}$ \\
\hline & & & $(\%)$ & \\
\hline PM & 200 & 31 & 55 & 65 \\
\hline PM & 400 & 32 & 35 & 49 \\
\hline PM & 800 & 27 & 20 & 44 \\
\hline FM & 200 & 19 & 48 & 74 \\
\hline FM & 400 & 27 & 36 & 65 \\
\hline FM & 800 & 19 & 22 & 41 \\
\hline AA & 200 & 11 & 14 & 11 \\
\hline AA & 400 & 14 & 14 & 30 \\
\hline AA & 800 & 21 & 12 & 45 \\
\hline VC & 200 & 7 & 8 & 6 \\
\hline VC & 400 & 9 & 6 & 21 \\
\hline $\mathrm{VC}$ & 800 & 7 & 5 & 8 \\
\hline $\mathrm{CF}$ & 50 & -16 & 68 & 56 \\
\hline $\mathrm{CF}$ & 100 & 2 & 73 & 43 \\
\hline $\mathrm{CF}$ & 200 & 8 & 68 & 58 \\
\hline
\end{tabular}

${ }^{\mathrm{z}} \mathrm{PM}$, poultry manure compost; FM, feather meal; AA, alfalfa meal; VC, vermicastings; $\mathrm{CF}$, chemical fertilizer; Amend, amendment treatment; Rate is $\mathrm{mg}$ of total $\mathrm{N}$ applied per pot.

among the amendments were largely dependent on interaction with application rate.
The K supply rate of all amendments except FM exceeded that of the CF200 treatment and the control. When compared at the same rate, cumulative $\mathrm{K}$ in the $\mathrm{VC}$ treatment was significantly higher than in the PM and FM treatments. For cumulative $S$, a significant amendment effect was detected, with an amendment ranking of $\mathrm{VC}>\mathrm{CF}>$ Control $=\mathrm{FM}=\mathrm{PM}=\mathrm{AA}$.

\section{DISCUSSION}

\section{Nutrient Supply Rates}

The FM, PM and AA traditionally would have been described as organic ammoniates (Rubins and Bear 1942) which accurately characterizes the high release of $\mathrm{NH}_{4}{ }^{+}$during early decomposition. Reintroduction of such a descriptor may be useful for reminding users of these materials that a stabilization period may be required to avoid toxicity problems. The high $\mathrm{NH}_{4}{ }^{+}-\mathrm{N}$ concentration in the PM indicates that this material was not fully composted (despite the description of the manufacturer) and it posed the highest risk for causing $\mathrm{NH}_{3}$ toxicity. Improperly composted poultry manure may also pose a health risk if applied to fresh vegetables such as lettuce. Among PM, FM and AA, the concentration of $\mathrm{NH}_{4}{ }^{+}$in the amended soil was lowest in the AA, where the lowest inhibitory effect on seedlings was also observed. Under certain conditions, however, alfalfa could cause $\mathrm{NH}_{3}$ toxicity (Ells et al. 1991).

The high concentration of available nutrients in the soil after a 4-d incubation of the AA and PM treatments is not surprising with $\mathrm{NH}_{4}{ }^{+}-\mathrm{N}$ accounting for between 10 and $24 \%$ of the total $\mathrm{N}$ in the amendments. Rubins and Bear (1942) estimated that $47 \%$ of $\mathrm{N}$ in alfalfa and $33 \%$ of $\mathrm{N}$ in poultry manure was water soluble. After removal of soluble $\mathrm{N}$, only $4 \%$ of the residual $\mathrm{N}$ in alfalfa was nitrified over $20 \mathrm{~d}$ and there was net immobilization of $\mathrm{N}$ when washed poultry manure was applied to soil.

The mineral $\mathrm{N}$ results from the $\mathrm{KCl}$ and $\mathrm{PRS}^{\mathrm{TM}}$ probe analyses at $4 \mathrm{~d}$ correspond well with the mineral nitrogen analysis of the amendments shown in Table1. However, they do also suggest that some of the $\mathrm{NH}_{4}{ }^{+}$in the PM, FM and AA treatments was nitrified in the first $4 \mathrm{~d}$ of the incubation. Cordovil et al. (2005) found that $\mathrm{NH}_{4}{ }^{+}$in organic amendments was nitrified very quickly, and remained low through most of their incubation period. For the PM, FM and AA treatments, $\mathrm{NO}_{3}{ }^{-}$levels decreased with rate at the 4 d period (Table 6), which indicates that nitrification may have been inhibited at the high rates of amendment application.

The $\mathrm{N}$ availability in FM has been reported to be low (Williams and Nelson 1992) due to the keratin structure of the feather (Choi and Nelson 1996a). Choi and Nelson (1996a) reported that only $17.8 \%$ of $\mathrm{N}$ was released from finely ground, but otherwise unaltered feathers. However, the availability of $\mathrm{N}$ can be increased to $45 \%$ of $\mathrm{N}$ using microbial hydrolysis (Choi and Nelson 1996b), or 52\% using steam hydrolysis (Choi and Nelson 1996a). When feather meal and alfalfa meal were applied at the same rate of $\mathrm{N}_{\text {tot }}$ to potted tomato transplants, feather meal produced a superior growth response whereas alfalfa meal application 
resulted in retarded growth and leaf distortion (Gagnon and Berrouard 1994). A similar delay in growth was observed in our study. The high initial $\mathrm{NO}_{3}{ }^{-}$content in the $\mathrm{VC}$, relative to $\mathrm{NH}_{4}{ }^{+}-\mathrm{N}$, is consistent with that found by other authors (Parle 1963; Warman and AngLopez 2002), and is an indication of maturity (Jimenez and Garcia 1989).

The $\mathrm{N}$ application rates of the CF were set at $25 \%$ of the total $\mathrm{N}$ rates of the organic amendments as a baseline comparison, assuming that all of the $\mathrm{N}$ in the $\mathrm{CF}$ would become available quickly. The $\mathrm{N}$ in the $\mathrm{CF}$ did become available quickly as was shown in Table 6. Of all the amendments, the AA nitrogen supply pattern appeared to most closely resemble the ammonium-nitrate fertilizer. The lowest rates of the PM and FM were similar to the highest rate of CF, but otherwise exceeded the $\mathrm{N}$ availability provided by the $\mathrm{CF}$. This clearly indicates that more than $25 \%$ of the total $\mathrm{N}$ in the PM and FM should be expected to become available.

The availability of $\mathrm{P}$ from organic amendments is largely influenced by the form of $\mathrm{P}$ in the amendment (Barnett 1994). The $\mathrm{P}$ content and form in an amendment can also influence microbial decomposition of substrates in the composting process, which will then also influence availability of other nutrients. As suggested by Brown et al. (1998) a total C:P ratio of 120:1 to $140: 1$ is required for proper composting. The total $\mathrm{C}: \mathrm{P}$ ratio of $\mathrm{FM}$ and $\mathrm{AA}$ was close to $240: 1$; however, the $\mathrm{C}: \mathrm{P}$ ratio of the VC was approximately 118:1 and the PM was 14:1. Warman and AngLopez (2002) found the C:P ratio of three mature vermicomposts ranged from 19:1 to 61:1. The vermicomposting of organic wastes has generally been found to increase $\mathrm{P}$ availability relative to incubation in soil without earthworms (Ghosh et al. 1999). With these C:P ratios shown above, the PM and VC were expected to mineralize $\mathrm{P}$ while the AA and FM were expected to immobilize P (Stevenson and Cole 1999). High $P$ availability was expected in the PM (Williams and Nelson 1992) but P was immobilized in the VC, AA and FM treatments, or it was adsorbed in the soil. The VC was not a raw substrate, rather, it was a stable material that had already undergone decomposition and, therefore, had lower $\mathrm{P}$ supply than might otherwise be anticipated.

There were several interesting results related to nutrient supply rate. First, the nitrogen supply rates increased quickly and then remained constant for an extended period of time, with only slight declines in supply rates after 6 mo. Each burial of PRS probes was intended to measure $\mathrm{N}$ being mineralized only during the 2-wk burial period, minimal residual $\mathrm{N}$ from previous burials was expected to be measured. With this assumption, it appears that $\mathrm{N}$ mineralization as shown by supply rates measured in timing 3 were sustained through timing 7 (15 wk) and hence $\mathrm{N}$ mineralization rates. Other reports of mineralization from organic amendments show a decline in mineralization with time (Cordovil et al. 2005). Movement of previously mineralized $\mathrm{N}$ through the moist, sandy soil to the membrane surface cannot be ruled out, and would help to explain the sustained $\mathrm{N}$ supply rates. Alternatively, the mineralization of the organic amendments may have been prolonged under the conditions of the experiment.

Second, although there was a significant rate effect on the cumulative supply of most nutrients, there were few significant differences between rates of an amendment and differ- ences were not proportional to the increases in application rates. In contrast, Cordovil et al. (2005) found that increasing organic amendment always resulted in increases in available $\mathrm{N}$ and that mineral $\mathrm{N}$ formation was proportional to the quantity of waste applied. Third, no significant increase in available $\mathrm{P}$ or $\mathrm{S}$ was measured for most treatments compared with the control. This may have been a result of immobilization of nutrients, or, in the case of $\mathrm{P}$, adsorption in the soil.

We hypothesize that the soil, with low organic matter and fertility, did not have the biological capacity to quickly decompose high rates of the amendments. We selected the soil for its low availability of nutrients; in its natural environment the soil supported only a sparse cover of perennial grasses and forbs. It is clear, however, that the soil biological community can respond quickly to the addition of organic matter, and we did measure a rapid increase in nutrient supply rates over the first $28 \mathrm{~d}$. However, the reserve of nutrients in the soil may have been so low that it resulted in nutrient imbalances for microbial decomposition, as would be indicated by immobilization of some nutrients, particularly $\mathrm{P}$ and $\mathrm{S}$. This is the most probable explanation for the unexpectedly low $\mathrm{N}$ supply measured for the 400 and 800 rate treatments. An assessment of soil microbial respiration would have been very useful in evaluating this hypothesis.

During the first $18 \mathrm{~d}$ of incubation, $\mathrm{NH}_{4}{ }^{+}$levels increased with rate of amendment, however, the $\mathrm{NO}_{3}{ }^{-}$levels remained constant. This may indicate that nitrification of $\mathrm{NH}_{4}^{+}$was inhibited as amendment rates increased. After $18 \mathrm{~d}$, however, the $\mathrm{NH}_{4}{ }^{+}$levels were very low, and the difference in $\mathrm{NO}_{3}{ }^{-}$ among the amendments was still relatively small.

The low nutrient supply rates in the 400 and 800 treatments relative to the 200 treatments may also have been associated with the PRSTM probes. The ion exchange membranes of the PRS ${ }^{\mathrm{TM}}$ probes have a limited capacity to store nutrients (Qian and Schoenau 2002b). An accounting for total nutrients compared with the ion-holding capacity of the probes revealed that the highest measurements approached but did not exceed capacity. Regardless, a limitation in capacity could not explain the observed rate effect for treatments with low overall nutrient supply rates that never approached membrane capacity.

The build up of nutrients in the containers may also have influenced the rate of amendment decomposition and nutrient supply. An abundance of a nutrient in solution may result in slower mineralization of that nutrient from the organic matter. Clearly this was not the case for $\mathrm{P}$ and $\mathrm{S}$.

A severely impoverished soil was used in this study to produce a maximum treatment effect. A clear amendment effect was measured at low rates of application. We hypothesize, however, that a stronger rate effect would have been measured in a soil with low to moderate fertility where a better balance of nutrients would be present as well as a more established microbial community. The use of an impoverished soil did, however, provide valuable insights into the importance of a balance of nutrients for microbial decomposition of the amendments.

\section{PLANT YIELD}

The suppressed growth of lettuce and orchardgrass by the high rates of the FM and PM was most likely related to phytotoxi- 
city (Jimenez and Garcia 1989). The supply of $\mathrm{NH}_{4}{ }^{+}$in these two amendments was high during the first 4 wk of measurements, and then abruptly declined. Ammonium salts at an alkaline $\mathrm{pH}$ may also inhibit plant growth. Using a composted PM in a growth room study with raspberries, Atiyeh et al. (2001) also attributed poor shoot growth to burning of roots due to high $\mathrm{NH}_{4}{ }^{+}$content in the compost. The high $\mathrm{NH}_{4}{ }^{+}$content accompanied by alkaline conditions may also cause an accumulation of $\mathrm{NO}_{2}^{-}$; excess $\mathrm{NO}_{2}^{-}$can be toxic to plants and important nitrifying microbes, specifically Nitrobacter (Warman 1980; Tisdale et al. 1985). Ells et al. (1991) found that $\mathrm{NH}_{3}$ toxicity inhibited cucumber germination and growth when AA was applied to sandy soils in a pot experiment; AA was not likely to be a problem, however, when applied to neutral or slightly acidic soils with a good buffering capacity. They also suggested that toxicity problems could be greater on soils with higher microbial activity, where a larger flush of $\mathrm{NH}_{3}$ would be produced during AA decomposition. The lettuce was particularly sensitive to the 800 rate treatments of FM and PM. While the growth of orchardgrass was initially suppressed, it did recover and responded well to the high $\mathrm{N}$ availability. In contrast, the early-maturing lettuce performed well in the VC treatment, as did the orchardgrass in the first few weeks. At the end of the experiment, however, the orchardgrass of the VC treatment was not growing as quickly and was showing initial signs of nitrogen deficiency. This indicates that while the vermicastings were suitable for seedlings and early crops, they did not provide adequate nutrients for long-season crops. Smith and Hadley (1988) found that summer cabbage transplants responded well to soil amended with FM, and outyielded an ammonium nitrate fertilizer. They suggested that the salt effect of the fertilizer might have slowed early growth. The potential toxicity of PM and FM on coarse textured soils can be avoided by applying the amendments several weeks before planting, or where possible, transplanting older seedlings including the starter potting mix around the roots.

\section{Apparent Nitrogen Recovery}

Nitrogen uptake by plant tissue can be influenced by many interacting factors. Certainly, limitations in other nutrients will influence the capacity of the plant to take up $\mathrm{N}$. If $\mathrm{N}$ is in abundant supply, luxury uptake of $\mathrm{N}$ may occur, resulting in higher concentrations of $\mathrm{N}$ than required for plant growth. Conversely, under good growing conditions the concentration of $\mathrm{N}$ in plant tissue may be relatively low as the plant grows quickly. These factors certainly confound the interpretation of $\mathrm{N}$ uptake by plants as indicators of $\mathrm{N}$ supply. We found that the lettuce responded well to the quickly available mineral $\mathrm{N}$ in the $\mathrm{VC}$ treatment. The orchardgrass, however, produced up to four times higher biomass than the lettuce over multiple harvests and a considerably longer time frame. While the VC treatments looked very promising in the first harvest of orchardgrass, later harvests showed a decline in plant productivity relative to the other amendments; the VC treatments did not provide a longterm supply of N. In contrast, the PM treatments initially inhibited the growth of lettuce, and to a lesser extent orchardgrass, but the higher long-term supply of $\mathrm{N}$ to the orchardgrass produced yields comparable to the $\mathrm{VC}$ treatments.
While the $\mathrm{KCl}$ extraction was effective in measuring the ANR via soil processes, the orchardgrass was a good biological indicator of the influence of nutrient interactions on the plants. The VC treatment produced a consistent ANR using both techniques with an ANR of approximately $10 \%$ at all application rates. This indicates that the material was mature and an excess of $\mathrm{N}$, which would be indicated by declining ANR, was not reached.

In the PM and FM treatments, approximately $50 \%$ of the $\mathrm{N}_{\text {tot }}$ applied at the 200 rate was available after $4 \mathrm{~d}$, and was primarily in the form of $\mathrm{NH}_{4}{ }^{+}$. For $\mathrm{PM}$ and FM, decreasing ANR-with increasing rate, as determined by $\mathrm{KCl}$ extraction, may be a result of higher gaseous losses of $\mathrm{N}$, or inhibition of mineralization at high rates due to excess mineral $\mathrm{N}$ in the soil (Stanford and Smith 1972) or ion toxicity problems. The lower ANR after 6 mo compared with that after $4 \mathrm{~d}$ is most likely due to gaseous losses.

The ANR of the AA was relatively low but appeared to increase with rate. The $\mathrm{N}$ in AA was relatively slow to become available compared with the VC, FM, and PM. A good estimate is hard to provide due to the rate effect, however, one may expect ANR to range from 10 to $40 \%$ when alfalfa is applied at 200 to $400 \mathrm{~kg} \mathrm{ha}^{-1}$ of total N; ANR would be expected to increase with increases in tissue $\mathrm{N}$ content due to lower likelihood of immobilization. Overall, the low $\mathrm{N}$ supply rate and ANR for $\mathrm{VC}$ is probably related to its high maturity and composition; the worms were fed mature compost, grain and peat moss. Other vermicomposts may perform differently.

The ANR of the CF was lower than expected, especially as measured by the orchardgrass. A deficiency of some other nutrient, which may have been provided by the organic amendments, is the most likely explanation. The ANR of the $\mathrm{CF}$ was comparable to the lower rates of the PM and FM as measured by $\mathrm{KCl}$ extraction at 6 mo (Table 8 ). $\mathrm{By} \mathrm{KCl}$ extraction, the ANR of the CF decreased from the sampling at $4 \mathrm{~d}$ as opposed to at $6 \mathrm{mo}$. As with the organic amendments, losses of $\mathrm{N}$ due to volatilization or leaching are the most probable explanations for the decrease in ANR.

\section{CONCLUSIONS}

Vermicastings are considered a mature soil amendment with $10 \%$ of total $\mathrm{N}$ available, much of which was available immediately. The VC was safe and effective for a sensitive crop with a short maturity such as lettuce; however, the relatively low nutrient-supplying power may limit the productivity of longer growing crops. Both FM and PM provided more $\mathrm{N}$ than the AA and VC treatments, resulting in good productivity of longer growing crops, despite initial toxicity issues. From 50 to $70 \%$ of the total $\mathrm{N}$ in PM and FM is expected to become available for plant uptake, but high releases of ammoniacal $\mathrm{N}$ shortly after application may inhibit sensitive crops. The AA was an effective, consistent amendment with intermediate $\mathrm{N}$-supplying power ranging from 10 to $40 \%$ of the total N. Increasing application rates of amendments will not necessarily result in corresponding increases in short-term nutrient supply due to constraints in decomposition. Nutrient balance must be accounted for 
when applying any of the amendments, particularly when applied to an impoverished soil; $\mathrm{P}$ supplements may be required, particularly with the $\mathrm{VC}, \mathrm{FM}$ and $\mathrm{AA}$.

\section{ACKNOWLEDGEMENTS}

The authors gratefully acknowledge funding provided by the Nova Scotia Department of Agriculture and Fisheries Technology Development Program, and support provided by Western Ag Innovations, Jolly Farmer, Archibald Farms, Atlantic Canadian Organic Regional Network, Derek Lynch, Kate Punnett and Brian Ives.

Atiyeh, R. M., Edwards, C. A., Subler, S. and Metzher, J. D. 2001. Pig manure vermicompost as a component of a horticultural bedding plant medium: effects on physicochemical properties and plant growth. Bioresour. Technol. 78: 11-20.

Atiyeh, R. M., Subbler, S., Edwards, C. A., Bachman, G., Metzger, J. D. and Shuster, W. 2000. Effects of vermicomposts and composts on plant growth in horticultural container media and soil. Pedobiologia 44: 579-590.

Barnett, G. M. 1994. Phosphorus forms in animal manure. Bioresour. Technol. 49: 139-147.

Brown , K. H., Bouwkamp J. C. and Gouin, F. R. 1998. Chemical characterization and nitrogen mineralization potentials of vermicomposts derived from differing organic wastes. Pages 231-239 in C. A. Edwards and E. F. Neuhauser, eds. Earthworms in waste and environmental management. SPB Academic Publishing, The Hague, the Netherlands.

Castellanos, J. Z. and Pratt P. F. 1981. Mineralization of manure nitrogen - correlation with laboratory indexes. Soil Sci. Soc. Am. J. 45: 354-357.

Choi, J. and Nelson, P. V. 1996a. Developing a slow-release nitrogen fertilizer from organic sources: II. Using poultry feathers. J. Am. Soc. Hortic. Sci. 121: 634-638.

Choi, J. and Nelson, P. V. 1996b. Developing a slow-release nitrogen fertilizer from organic sources: III. Isolation and action of a feather-degrading Actinomycete. J. Am. Soc. Hortic. Sci. 121: 639-643.

Cordovil, C. M. D. S., Couinho, J., Goss, M. and Cabral, F. 2005. Potentially mineralizable nitrogen from organic materials applied to a sandy soil: fitting the one-pool exponential model. Soil Use Manage. 21: 65-72.

Douglas, B. F. and Magdoff F. R. 1991. An evaluation of nitrogen mineralization indices for organic residues. J. Environ. Qual. 20: 368-372.

Ells, J. E., McSay, A. E. and Workman, S. M. 1991. Toxic effects of manure, alfalfa, and ammonia on emergence and growth of cucumber seedlings. Hortic. Sci. 26: 380-383.

Gagnon, B. and Berrouard, S. 1994. Effects of several organic fertilizers on growth of greenhouse tomato transplants. Can. J. Plant Sci. 74: 167-168.

Ghosh, M., Chattopadhyay, G. N. and Baral K. 1999. Transformation of phosphorus during vermicomposting. Bioresour. Technol. 69: 149-154.

Hadas, A. and Portnoy, R. 1994. Nitrogen and carbon mineralization rates of composted manures incubated in soil. J. Environ. Qual. 23: 1184-1189.

Jimenez, E. I. and Garcia, V. P. 1989. Evaluation of city refuse compost maturity: A review. Biological Wastes 27: 115-142.

Littell, R. C., Henry, P. R. and Ammerman, C. B. 1998. Statistical analysis of repeated measures data using SAS procedures. J. Anim. Sci. 76: 1216-1231.

Littell, R. C., Milliken, G. A., Stroup, W. W. and Wolfinger, R. D. 1996. SAS ${ }^{\circledR}$ system for mixed models. SAS Institute, Inc., Cary, NC. 633 pp.
Ma, B. L., Dwyer L. M. and Gregorich E. G. 1999. Soil nitrogen amendment effects on seasonal nitrogen mineralization and nitrogen cycling in maize production. Agron. J. 91: 1003-1009.

Montgomery, D. C. 2001. Design and analysis of experiments. 5th ed. Wiley, New York, NY. 684 pp.

Moreau, T. L. 2004. An evaluation of alternative pest controls for the Colorado potato beetle, Leptinotarsa decemlineata (Say) on organic potatoes. Nova Scotia Agricultural College, Dalhousie University, Halifax, NS. 98 pp.

N'Dayegamiye, A., Royer, R. and Audesse P. 1997. Nitrogen mineralization and availability in manure composts from Québec biological farms. Can. J. Soil Sci. 77: 345-350.

Parle, J. N. 1963. A microbiological study of earthworm casts. J. Gen. Microbiol. 31: 13-22.

Qian, P. and Schoenau, J. J. 1995. Assessing nitrogen mineralization from soil organic matter using anion exchange membranes. Fert. Res. 40: 143-148.

Qian, P. and Schoenau, J. J. 2002a. Availability of nitrogen in solid manure amendments with different C:N ratios. Can. J. Soil Sci. 82: 219-225.

Qian, P. and Schoenau, J. J. 2002b. Practical applications of ion exchange resins in agricultural and environmental soil research. Can. J. Soil Sci. 82: 9-21.

Rubins, E. J. and Bear, F. E. 1942. Carbon-nitrogen ratios in organic fertilizer materials in relation to the availability of their nitrogen. Soil Sci. 54: 411-423.

SAS Institute, Inc. 1999. SAS onlineDoc ${ }^{\circledR}$. Version 8. SAS Institute Inc., Cary, NC.

Smith, S. R. and Hadley, P. 1988. A comparison of the effects of organic and inorganic nitrogen fertilizers on the growth response of summer cabbage (Brassica olearacea var. capitata cv. Hispi $\mathrm{F}_{1}$ ). J. Hortic. Sci. 63: 615-620.

Stanford, G. and Smith, S. J. 1972. Nitrogen mineralization potentials of soils. Soil Sci. Soc. Am. Proc. 36: 465-472.

Stevenson, F. J. and Cole, M. A. 1999. Cycles of soil. John Wiley \& Sons, Inc., Toronto ON. pp. 191-254, 279-325.

Subler, S., Blair, J. M. and Edwards, C. A. 1995. Using anion exchange membranes to measure soil nitrate availability and net nitrification. Soil Biol. Biochem. 27: 911-917.

Ta, T. C. and Faris, M. A. 1990. Availability of N from ${ }^{15} \mathrm{~N}-$ labeled alfalfa residues to three succeeding barley crops under field conditions. Soil Biol. Biochem. 22: 835-838.

Tisdale, S. L., Nelson, W. L. and Beaton, J. D. 1985. Soil fertility and fertilizers, 4th ed. Macmillan Publishing Company, New York, NY. 754 pp.

Warman, P. R. 1980. The effect of Amprolium and Aureomycin on the nitrification of poultry manure-amended soil. Soil Sci. Soc. Am. J. 44: 1333-1334.

Warman, P. R. and Cooper, J. M. 2000a. Fertilization of a mixed forage crop with fresh and composted chicken manure and NPK fertilizer: effects on dry matter yield, legume content, and soil and tissue N, P, K. Can. J. Soil Sci. 80: 337-344.

Warman, P. R. and Cooper, J. M. 2000b. Fertilization of a mixed forage crop with fresh and composted chicken manure and NPK fertilizer: Effects on soil and tissue $\mathrm{Ca}, \mathrm{Mg}, \mathrm{S}, \mathrm{B}, \mathrm{Cu}, \mathrm{Fe}, \mathrm{Mn}$ and Zn. Can. J. Soil Sci. 80: 345-452.

Warman, P. R. and AngLopez, M. J. 2002. The chemical properties of vermicompost derived from different feedstocks. [CD ROM] Proceedings 2002 International Symposium, Composting and Compost Utilization, 2992 May 6-8. Columbus, OH.

Williams, K. A and Nelson, P. V. 1992. Low, controlled nutrient availability provided by organic waste materials for Chrysanthemum. J. Am. Soc. Hortic. Sci. 117: 422-429. 
Zheljazkov, V. D. and Warman, P. R. 2002. Comparison of three digestion methods for the recovery of 17 plant essential nutrients and trace elements from six composts. Compost Sci. Util. 10: 197-203.
Ziadi, N., Simard, R. R., Allard, G. and Lafond, J. 1999. Field evaluation of anion exchange membranes as a $\mathrm{N}$ soil testing method for grasslands. Can J. Soil Sci. 79: 281-294. 
